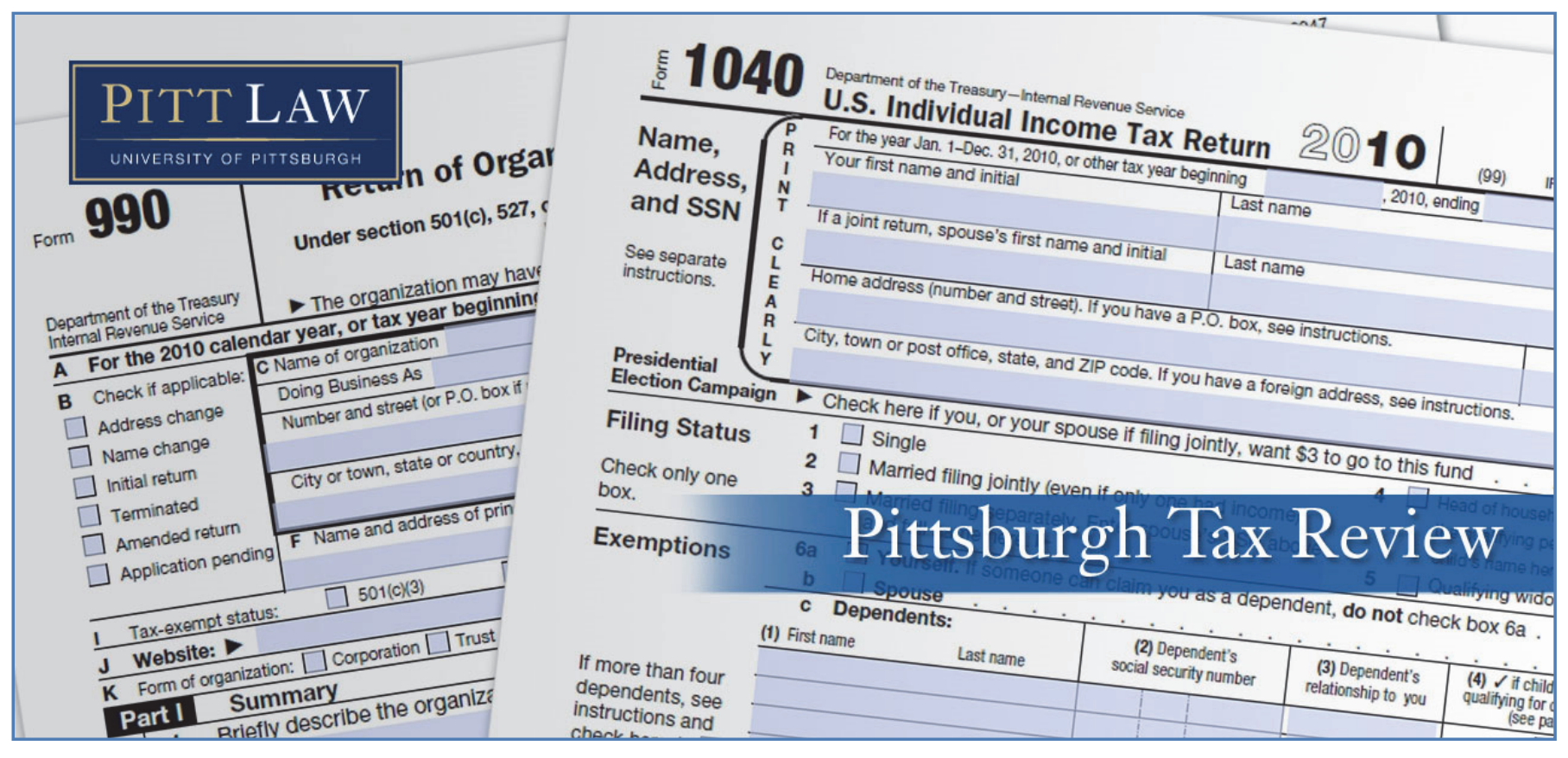

Volume 16 (2019) | ISSN 1932-1821 (print) 1932-1996 (online)

DOI 10.5195/taxreview.2019.93 | http://taxreview.law.pitt.edu

\title{
STRATEGIES TO MATERIALIZE GENDER EQUALITY IN TAX LAW AND DOCTRINE: REWRITTEN TAX OPINIONS
}

\author{
Åsa Gunnarsson
}

\section{(c) BY-NC-ND}

This work is licensed under a Creative Commons Attribution-Noncommercial-No Derivative Works 3.0 United States License.

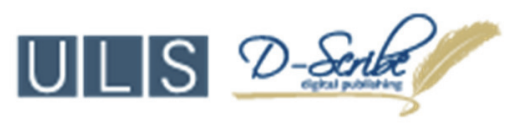

This journal is published by the University Library System of the University of Pittsburgh as part of its D-Scribe Digital Publishing Program, and is cosponsored by the University of Pittsburgh Press. 


\title{
STRATEGIES TO MATERIALIZE GENDER EQUALITY IN TAX LAW AND DOCTRINE: REWRITTEN TAX OPINIONS
}

\author{
Åsa Gunnarsson ${ }^{*}$
}

A constant theme in feminist legal studies is to challenge the objectivity and impartiality of law, which the dominant view in legal scholarship perceives as an axiomatic condition. In the project of rewriting tax law cases by applying feminist methods and perspectives, ${ }^{1}$ the authors had to challenge the line between law and politics that is taken for granted. Generally, one frame of reference is the national-state, under the rule of law perspective, creating an imaginary concept that all citizens are equally treated under the law. In the Nordic tradition, this is what we call the dogmatic position, reasoned from a base of formal-logic analyses with the aim to uphold an internal normative coherence. ${ }^{2}$ The tradition is rather nontheoretical, but still it sets a normative standard on boundaries of normality in law. The self as an autonomous competent individual is the standard and matters of relational dependency are defined as different and are excluded from the legal discourse. The abstract concept of the individual has shaped the idea of privacy, not in the sense of integrity, but as a contextual value of a private sphere, free from public intervention. On the other side of the dichotomy, the public sphere has been the scene of politics and the intervention of law. Consequently, the understanding of ourselves and the world around us is influenced by the division between the public world of political life and marketplace activities and the domestic, private life of care and personal relations. ${ }^{3}$

\footnotetext{
${ }^{*}$ Umeå University, Faculty of Social Sciences, Umeå Forum for Studies on Law and Society.

${ }^{1}$ FEMINIST Judgments: Rewritten TAX Opinions (Bridget J. Crawford \& Anthony C. Infanti eds., 2017).

2 Åsa Gunnarsson et al., Reflecting the Epistemology of Law-Exploiting Boundaries, in Exploiting the Limits of Law: Swedish Feminism and the Challenge to Pessimism (Åsa Gunnarsson et al. eds., 2007).

${ }^{3}$ Margaret Davies, Notes Towards an Optimistic Feminism: A Long View, in EXPLOITING THE Limits of LAW, supra note 2, at 213; see NiCOLA LACEY, UNSPEAKABLE SUBJECTS: FEMINIST ESSAYS
}

Pitt Tax Review | ISSN 1932-1821 (print) 1932-1996 (online)

DOI 10.5195/taxreview.2019.93 | http://taxreview.law.pitt.edu 
The Nordic dogmatic position has served as the basis for the design of tax doctrines, resulting in a separation of tax law from underlying values and political-economic discourses. ${ }^{4}$ This demarcation has produced what is regarded as neutral tax law concepts detached from societal contexts. The private/domestic dichotomy becomes invisible and the normative concepts of justice are only elaborated in relation to issues concerning the public sphere. Looking at the normative structures of tax law and the legislative prerequisites for what should or should not be regulated, a divide between public and private life in various tax law regulations is often present. From an everyday life perspective, the economic injustices reside in women's domestic work in the private sphere, where care work is totally neglected as a productive activity with economic value. ${ }^{5}$ Those economic implications that are significant for female labor supply in relation to household production are the division and heterogeneity of labor in the households that occur once children arrive. The socioeconomic culture that makes women follow the path-dependent route to "choose" between working in the market and taking care of the child in the home is primarily the basic reason for the fall of female labor supply. ${ }^{6}$ Labor force participation and the division of unpaid work are two socioeconomic gender gaps that are relevant for the distributional and allocative impact of tax laws. These gender gaps also partly feed a chain of other gender gaps relevant for taxation, such as the fact that women earn less, have less wealth, have lower pensions, and risk poverty to a higher degree. ${ }^{7}$

For feminist tax scholars, it is a major challenge to explain how these socioeconomic realities will produce gender-different outcomes when the dominant tax discourse is that tax systems and tax policies are formally gender neutral. And an even bigger challenge is to produce recommendations

\footnotetext{
In Legal and Social Theory (1998); see also Åsa GunNarsson \& Eva-Maria Svensson, GENUSRÄTTSVETENSKAP (2009).

${ }^{4}$ GunNARSSON \& SvenSSON, supra note 3, at 6-9.

${ }_{5}^{5}$ Åsa Gunnarsson, Tax Law Directions for Erasing the Public/Private Divide in Everyday Life Economy, in TRACING THE WOMEN-Friendly Welfare STATE: Gendered Politics OF EVERYdAY LIFE IN SWEDEN 38 (Åsa Gunnarsson ed., 2013).

${ }^{6}$ See generally PAtricia ApPs \& RAy ReEs, Public EConOmics AND the Household (2009).

${ }^{7}$ Åsa GunNarsson et AL., Directorate Gen. FOR INTERNAL Policies, GENDER EQUality AND TAXATION IN THE EUROPEAN UNION 39-40 (2017), http://www.europarl.europa.eu/RegData/etudes/ STUD/2017/583138/IPOL_STU(2017)583138_EN.pdf.
}

Pitt Tax Review | ISSN 1932-1821 (print) 1932-1996 (online) DOI 10.5195/taxreview.2019.93 | http://taxreview.law.pitt.edu 
on how substantive gender equality will be achieved by rewriting tax laws and by introducing feminist methods and perspectives in the interpretation of tax laws. In the feminist project of critically rewriting tax opinions from United States court cases, I can, coming from a Nordic gender equality law context, see yet another challenge, which is the challenge of pessimism regarding the potential for legal change. This analysis may sound cryptic, so let me explain.

The strategy to show the gender bias in individual tax cases will for sure contribute to the materialization of gender equality issues that have the potential to change tax law and doctrine. It is also a very natural approach, as making law through case law is a central part of the Anglo-American law tradition. But still, the rewriting of tax cases does not give much hope for legal change on a structural level in the near future. And that made me jump back in time to a line of thought that we explored some ten years ago about a noticed difference between the perceptions of optimism and pessimism in legal feminism. The faith in law reform to achieve substantial progress for women's social position seems to have faded from legal feminism based in a liberal state context. In contrast, the optimistic view on both policy and law reforms as effective methods for promoting substantive change is still part of the women's law tradition in the Nordic social-democratic welfare-state context. ${ }^{8}$ The differences are understandable, as the sources of pessimism are more obvious in jurisdictions with conservative-liberal views on the role of the state, and also where neoliberalism has gained a strong position, subordinating most aspects of social justice in the legal reform discourse. On the other hand, in the social-democratic Nordic welfare-state model, gender equality policies have historically been developed in tandem with the welfare-state ideology, and have expressed a structural understanding of gender inequalities. ${ }^{9}$ Explicit and extensive legislation has promoted gender equality, consisting of constitutional provisions, antidiscrimination rules, and, probably most importantly, a wide range of active legal measures. ${ }^{10}$

Reflections on a noticed pessimism among North American feminist legal scholars are of course our own, and it does not serve as a claim for the

\footnotetext{
${ }^{8}$ Gunnarsson et al., supra note 2, at 6-9.

${ }_{9}^{9}$ Eva-Maria Svensson \& Åsa Gunnarsson, Gender Equality in the Swedish Welfare State, 2 FEMINISTS@LAW, no. 1, 2012, at 11.

${ }^{10}$ See generally id.
}

Pitt Tax Review | ISSN 1932-1821 (print) 1932-1996 (online) DOI 10.5195/taxreview.2019.93 | http://taxreview.law.pitt.edu 


\section{6 | Pittsburgh Tax Review | Vol. 162019}

superiority of Nordic gender equality law or as an argument for the true and only women-friendly roadmap for social justice. As lawyers we are trained to argue from inside the boundaries of law in a contest of finding the "right," or maybe more accurately, the most competitive interpretation of the law. But this rationality of being competitive, to "win" the rhetoric of legal interpretations, ought not to be guiding the feminist way of reasoning in regard to alternative understandings of theories, methods, and the practice of tax law. I advocate for the strategy of avoiding the trap of building new types of boundaries by arguing for the best or right strategies on how to achieve social justice for women. So, instead of choosing between contradictory positions such as pragmatism or idealism, or women's rights and intersectional perspectives, or postmodernist views versus radical feminism, we should allow ourselves to explore combined strategies and avoid labels. ${ }^{11}$

Tove Stang Dahl, one important pioneer in Nordic women's law tradition, is for me a great example of a feminist legal scholar with an optimistic view on how law could be used to promote substantial gender equality. ${ }^{12}$ She showed in her writings and projects, already many decades ago, an insightful roadmap from which a multitude of alternative routes could be picked. ${ }^{13}$ She studied women's living conditions in relation to law from an everyday life perspective with the purpose of basing a critique of law on women's different experiences. ${ }^{14}$ It resulted in an important strategy for legal activism and political debate, which was to problematize to what extent law expresses the interests of men in opposition to women's interestsunderstood from a pluralistic perspective and not a monistic one - and it also detects and defines those blank spots in law, normally in relation to the private sphere, that have left important issues of justice for women unregulated. ${ }^{15}$ She also developed her methods in connection to legal activism, which emphasized that theories and practices are intertwined both

${ }^{11}$ See generally Davies, supra note 3, at 213.

${ }^{12}$ See Tove Stang Dahl, Women's LaW: An InTROduction to Feminist JURISPRUdENCE 12 15, 28-36, 55-56 (1987).

${ }^{13} I d$.
${ }^{14} I d$.
${ }^{15} I d$.

Pitt Tax Review | ISSN 1932-1821 (print) 1932-1996 (online) DOI 10.5195/taxreview.2019.93 | http://taxreview.law.pitt.edu 
on a structural and an individual level. ${ }^{16}$ Another important part of her writings was the recognition of comparative studies and studies in the history of law to be used in the deconstruction of legal concepts, sex neutral subjects and principles, and to trace normative stereotypes and discriminatory practices. ${ }^{17}$

To conclude, optimistic legal feminism is based in pragmatic outcomes, not idealism. Reading the World Economic Forum's yearly Global Gender Gap Report, it is obvious that the social-democratic Nordic welfare model has delivered an infrastructure for gender equality that has had a substantial impact on women's rights, social justice, and independence. ${ }^{18}$ Looking at Sweden, women's economic independence has particularly been improved through reforms in the fields of labor, tax, and social security law. The introduction of an independent income tax for spouses in 1971 is one of the most important reforms in this context. However, it is rather obvious that redistributive motives behind taxes and benefits to improve gender equality are connected to a political paradigm. Even though most political parties adhere to gender equality as a central quality of Swedish society, the level of ambition differs. The more conservative on the political scale, the more emphasis is placed on individual rights to achieve gender equality than law reforms for structural change. ${ }^{19}$ But still, we have had a shared view in politics about direction, which has created a sustainable base for gender equality politics. Family-based income tax and social benefit systems have been outdated for a long time, but the political landscape is changing. We now have a political party that has taken a stand against the overarching goal of Swedish national gender equality policies by, among many things, suggesting a reintroduction of elements of joint taxation. This new challenge for the Swedish feminist project is a hint for us all to realize that there is no obvious end-point, but instead of pessimism it should encourage us to intensify our work to develop the body of feminist legal scholarship.

\footnotetext{
${ }^{16} I d$.

${ }^{17} \mathrm{Id}$.

${ }^{18}$ See generally World ECONOMIC FORUM, THE GLOBAL GENDER GAP REPORT 2018 (2018), http://www3.weforum.org/docs/WEF_GGGR_2018.pdf.

19 See Eva-Maria Svensson \& Åsa Gunnarsson, Structuralism Versus Individualism in Swedish Gender Equality Policy and Law, 26 NORDIC J. FEMINIST \& GENDER RES. 230 (2018).
}

Pitt Tax Review | ISSN 1932-1821 (print) 1932-1996 (online) DOI 10.5195/taxreview.2019.93 | http://taxreview.law.pitt.edu 
